\title{
Selfhood and Destiny: On Heidegger's Call for Poetic Self-Renewal in the Contemporary Age of Devastation
}

\author{
Marc Oliver D. Pasco
}

\begin{abstract}
This essay aims to map out the path of devastation that has left us homeless and, as the thinker Martin Heidegger says, frantically and thoughtlessly seeking for our identity. The first part of the paper will be an exposition on Heidegger's ideas concerning the history of oblivion and how this may aid us to see where we have to be at present. The second part will use for its point of departure Heidegger's insights on forgetfulness to explain how he perceives the possibility of salvation from such a threat by expounding on his ideas concerning the "fourfold" and its relationship with selfhood. The last part of the paper will then discuss his idea of poetic dwelling and how this is in fact the path towards an authentic re-building of the self in the midst of Being's withdrawal and devastation. Given Heidegger's contention that the destiny of the self is tied up with the destining of Being, this paper will show that it is only by thoroughly examining the destining of absence, oblivion and withdrawal issued by history itself that we may build ourselves once more. This time, we shall do so in a more essential way, more heedful of the directives inscribed in our very beings as the ones tasked to recover ourselves from the mire of forgetfulness, and as mortal dwellers on the earth, under the sky, awaiting the divinities.
\end{abstract}

KEYWORDS: Being, fourfold, oblivion of Being, poetic dwelling, selfhood, destiny

\section{INTRODUCTION}

If framed within the post-metaphysical paradigm, questions on the meaning of identity, on what underpins it, and on the consequent episte- 
mology seek for grounds outside the traditional monolithic discourse of the medieval distinction between body and soul. Instead, one either psychologically reduces identity to the level of drives or of the unconscious, or else, finds it in the cultural/politico-discursive network of social roles based on communicative relations. Today, more than ever, the forging of identity in any of its forms has been colonized by various political/capitalistic enterprises that seek to simulate various archetypal/typecasted human "forms" that can serve as mechanisms for leveling the otherwise countless configurations of the self. This is done in order to manipulate consumer behavior. In addition, with the advent of advanced media communications and the increasingly democratized public sphere of information, questions concerning selfhood have been transmuted and translated according to the medium available to the consumer. In other words, we are now afforded the chance to literally choose ourselves. We are given a considerable amount of power to design how we appear to others without necessarily having any specific motivation (be it malign or benevolent) behind it (beyond deception). What comes out is a purely spectacular self, as it were, one that is virtually unconditioned and always already (subconsciously) conjured. Faced with such a context the tendency of contemporary man has been either to retreat into an introverted virtual existence through social media, or to violently participate in exaggerated social spectacles so as to feel "normal."

This enigmatic notion of control over one's identity brings us to one of the most, if not the most, pressing question that one must grapple with if one is interested in salvaging any semblance of legitimacy in responding to the question of personhood. The new gods that we have forged for ourselves (mainly capital, and various forms of external/social control) with the intention of simulating models, that is, of idols for us to measure ourselves against, seem to have left us with a world in utter disarray. Now, more than ever, people are becoming more and more alienated from themselves as they seek to "spontaneously" construct identities based on the configurations offered to them by contemporary technological/ capitalistic ideologies. The sheer volume and availability of consumable identities in our society seem to have insidiously corrupted our ability to form dynamic and authentic selves. In other words, without a reliable compass, modern man is left homeless and alienated from himself. The lonely crowd propagates itself through the uninterrupted pronouncements (literally, "24/7") of the new gods that keep us in line, normalizing the processes of (identity) production by constantly (and ironically) threatening us with loneliness and alienation. 
This spontaneous implosion of selfhood as it constantly struggles to recover from the trauma of capitalistic/technological devastation is an occurrence that is not simply the result of anthropological intent. It is also not merely the result of the "natural" flow of history. According to the thinker Martin Heidegger, this leveling down of human possibilities, this ontological devastation of self in our current epoch, has been destined. ${ }^{1}$

Heidegger's insights are particularly valuable for us today. His seminal reading of the history of Western thought, of how it began its decline into oblivion in Plato's idealization of Being and reached its consummation in the age of modern technology, can serve as an appropriate point of departure for mapping out how contemporary man has been seemingly alienated from himself for such a long time. Heidegger firmly holds that man's essential nature is inextricably tied up with the essential unfolding of Being in history.

Throughout his career as a thinker, Heidegger boldly re-opened and tirelessly tackled various ideas and timeless questions in the history of thought in the hope of coming to grips with the yet un-thought ground upon which, he intimates, all questioning is possible in the first place. He is of course most noted for his critique of Western metaphysics, which he claimed to be the history of man's forgetfulness of the question of Being (Seinsvergessenheit). This forgetfulness of the question of Being, "Greek-ly" understood as presencing (das Anwesen), comes hand in hand with man's uncanny estrangement from himself.

According to Heidegger, "man's inability to see himself corresponds to the self-concealing of the lighting of Being" ("Anaximander Fragment" 26). Here, we observe that Heidegger does not view our alienation from our true essence as Dasein as a kind of "fault" that exclusively issues from our part, nor a "fate" that simply befalls our being, but as precisely the function of our being as being drawn in the history (Geschichte) of Being itself, of our essential belonging to the happening of Being as it discloses (alètheuein) and withholds itself to us in the different epochs of history. Therefore, if we are in any way interested in trying to conceive the meaning of our

${ }^{1}$ The word "destiny" or "destining" is used here within the context of Martin Heidegger's interpretation of the word Geschick. In his book, The Principle of Reason, he expounds: "We usually understand Geschick [destiny] as being that which has been determined and imposed through fate: a sorrowful, an evil, a fortunate Geschick. This meaning is a derivative one. For schicken ['sending'] originally denotes: 'preparing,' 'ordering,' 'bringing each thing to that place where it belongs'; consequently it also means to 'furnish' (From Goethe) and 'admit'; 'to appoint' [beschicken] a house, a room, means: 'to keep in good order,' 'straightened up and tidied.' (The Principle of Reason 61). 
being (as for instance, in the contemporary context), it will necessarily be derived from our relation to Being as it reveals itself to us in history. Our existing perception of ourselves, for instance as the masters and shapers of nature, and our relentless quest for social acceptance and normalcy particularly evident in today's age of social media, are ultimately derived from the historical transmutations of our understanding of what-is and what it means to be. As Heidegger states:

Certainly, the turning and turning away of being, if we pay sufficient heed to them, can never be represented as though they affected human beings only on particular occasions and at particular moments. Rather, the human essence resides in the fact that at all times it endures and dwells in one way or another within such turning or turning away. ("On the Question of Being" 308)

Hence, the history of the turning away and withdrawal of Being from thought (from Plato to the age of modern technology) issues from the historical destining of Being (das Geschick des Seins), and man, belonging to the essential and historical unfolding of Being "appropriately" responds with a particular manner of thinking "suited" to that which reveals (and conceals) itself from him. And since Being, essentially understood as presencing, naturally hides itself from thought in the age of metaphysics (which exclusively deals with the beingness of beings), the essence of man himself remains veiled from himself (as the being that is open to the hail of presencing). The way we understand ourselves for instance, as the rational animal, or as the self-conscious subject, therefore has its underpinnings in our understanding of Being in the age of metaphysics. Heidegger adds:

The history of Being is Being itself, and only Being. However, since Being claims human being for grounding its truth in beings, man is drawn into the history of Being, but always in regard to the manner in which he takes his essence from the relation of Being to himself and, in accordance with this relation, loses his essence, neglects it, gives it up, grounds it, or squanders it. ("Recollection in Metaphysics" 3-4)

Briefly, the way we understand our essence as human beings and the manner by which we comport ourselves towards beings is grounded upon and belongs to the history of Being to which we ourselves belong. Furthermore, Heidegger notes that the oblivion "does not simply befall the essence of being, as something apparently separate from the latter" ("On the Question of Being" 308). That it is in the proper essence (das Wesen) 
of Being that it escapes notice (lèthein), conceals, hides and denies itself from thought; and that hidden beneath the encrustations of metaphysics lies the possibility of a poetic retrieval (Wiederholung) and thoughtful remembrance (Andenken) of that which has been forgotten and most worthy of thought (das Denken). For him, the path towards the forgotten is the path towards recollection. The way to salvage ourselves from the constant threat of implosion and alienation is to salvage our essential relationship with Being itself.

This essay aims to map out this path of devastation that has left us homeless, and as Heidegger says, frantically and thoughtlessly seeking for our identity. The first part of the paper, which has been partially explained already, will be an exposition on Heidegger's ideas concerning the history of oblivion and how this may aid us to see where we have to be at present. The second part will use for its point of departure Heidegger's insights on forgetfulness to explain how he perceives the possibility of salvation from such a threat by expounding on his ideas concerning the "fourfold" and its relationship with selfhood. The last part of the paper will then discuss his idea of poetic dwelling and how this is in fact the path towards an authentic re-building of the self in the midst of Being's withdrawal and devastation.

Given Heidegger's contention that the destiny of the self is tied up with the destining of Being, this paper will show that it is only by thoroughly examining the destining of absence, oblivion and withdrawal issued by history itself that we may build ${ }^{2}$ ourselves once more. This time, however, it will be done in a more essential way, one more heedful of the directives inscribed in our very being as the ones tasked to recover ourselves from the mire of forgetfulness, as mortal dwellers on the earth, under the sky, awaiting the divinities. ${ }^{3}$

${ }^{2}$ The word "build" holds a special importance in the thought of Heidegger. Building, he says, is an original gathering that allows us to dwell authentically/poetically within the horizon of the truth of Being.

${ }^{3}$ This idea is gathered from Heidegger's later writings concerning the "fourfold." Heidegger describes each of the four as such: "Earth is the serving bearer, blossoming and fruiting, spreading out in rock and water, rising up into plant and animal... The sky is the vaulting path of the sun, the course of the changing moon, the wandering glitter of the stars, the year's seasons and their changes, the light and dusk of day, the gloom and glow of night, the clemency and inclemency of the weather, the drifting clouds and blue depth of the ether... The divinities are the beckoning messengers of the godhead. Out of the holy sway of the godhead, the god appears in his presence or withdraws into his concealment.... The mortals are the human beings. They are called mortals because they can die. To die means to be capable of death as death. Only man dies, and indeed continually, as long as he remains on earth, under the sky, before the divinities." ("Building Dwelling Thinking" 147-48) 
Marc Oliver D. Pasco, "Selfhood and Destiny: On Heidegger's Call for Poetic Self-Renewal"

\section{OBLIVION AND DEVASTATION}

In What Is Called Thinking, Heidegger contemplates on man's apparent flight from authentic thinking. He approaches the issue of this oblivion in the context of Nietzsche's thought. He says:

Nietzsche, who from his supreme peak saw far ahead of it all, as early as
the eighteen-eighties had for it the simple, because thoughtful, words:
"The wasteland grows." It means, the devastation is growing wider.
Devastation is more than destruction. Devastation is more unearthly
than destruction. Destruction only sweeps aside all that has grown up
or been built up so far; but devastation blocks all future growth and
prevents all building. (29)

Heidegger interprets this quote from Nietzsche within the ambit of the condition of modern technological society. He, of course, is speaking beyond the obvious forms of destruction and devastation happening on the earth. In a more basic sense, the modern paradigm of thought (heralded in Plato's Idea, pushed to its limit in Nietzsche's Will-to-Power, and consummated in the age of modern technology) fundamentally characterized by an obsessive preoccupation with measure and control, issues from the historical withdrawal of the proper matter of thought from man. The devastation mentioned by Nietzsche is not merely anthropological in nature. It issues from the self-unfolding of the history of Being itself. History, essentially understood, is constituted by a withdrawal, or a holding-back.

If we are to examine the devastation that Heidegger speaks about, it is safe to assume that it has something to do with how we stand in relation to Being. Since it is in our essential nature to be drawn towards what reveals itself to us, any understanding we might have of anything is inextricably tied with how the history of Being reveals these things to us, as it (Being itself) simultaneously withdraws from view. The history of the turning away and withdrawal of Being from thought (from Plato, to Nietzsche, to the age of modern technology) issues from the historical destining of Being (das Geschick des Seins), and man, belonging to the essential and historical unfolding of Being appropriately responds with a particular manner of thinking appropriate to that which reveals (and conceals) itself from him. Since Being, essentially understood as the very event of presencing, naturally hides itself from metaphysical and technological man (who exclusively deals with the beingness of beings), the essence of Dasein himself remains veiled from himself (as the being that is open to the hail of presencing). As he points out, "The reason is never exclusively or primarily that we men do not sufficiently reach out and 
turn toward what properly gives food for thought; the reason is that this most thought-provoking thing turns away from us, in fact has long since turned away from man" (What Is Called Thinking 17).

It therefore belongs to the proper essence of Being that it be forgotten, that is, devastated by its own withdrawal. For Heidegger, this event of withdrawal is of paramount importance. For him, "Withdrawal is an event. In fact, what withdraws may even concern and claim man more essentially than anything present that strikes and touches him" (What Is Called Thinking 9). If it therefore happens that we have forgotten our essential place in the world, it is not solely due to our own fault. Our ontological commitment to meaning as prescribed to us by our fundamental constitution as beingin-the-world predisposes us towards understanding phenomena. But this predisposition, the later Heidegger suggests, is informed by history, i.e., by the withdrawal of that which allows us to meaningfully encounter things in the world. Hence, forgetfulness is but a formal (re)configuration of a more fundamental relation towards that which is. The essential character of Dasein lies in his original belongingness (in any way, shape or form) towards the historical unfolding of Being. As Heidegger states, "Human beings do not decide whether and how beings appear, whether and how God and the gods or history and nature come forward into the clearing of being, come to presence and depart. The advent of being lies in the destiny of being" ("Letter on 'Humanism" 252).

The trail of devastation, the wasteland, the oblivion, therefore, is not simply the result of man's insatiable drive to conquer being through scientific and technological knowledge at the expense of "(human) nature." As Heidegger himself claims in one of his most famous works, Ge-stell or Enframing itself claims man for its own accomplishment in the history of Being. ${ }^{4}$ The very epoch (withdrawal) of the age of modern technology can be deemed as a simultaneous ontological transmutation of the formal comportment of Dasein towards the world. In other words, in such an age, man cannot but challenge-forth (Herausfordern) beings, including himself, to bend to in accordance with calculative will.

Simply put, devastation is destined. ${ }^{5}$ It may be argued therefore that man's seemingly frenetic yet pointless quest for authentic selfhood in

${ }^{4}$ See, The Question Concerning Technology and Other Essays.

${ }^{5}$ I must once again emphasize the nuance of the meaning of this word for Heidegger. Destining or destiny in the sense of Geschick for Heidegger does not connote the usual romanticized meaning of the word as with, for instance, two lovers being brought together by destiny. It rather means that given Dasein's incipient belongingness to the history of Being, he remains a respondent, albeit an active one, to "questions" posed to him by Being at different epochs of history. 
the contemporary epoch is "providential," as it were. As with Being itself, man's comportment towards that which appears and unfolds itself in history, including the ontological dynamisms of his thrownness and futural projection, is primordially framed within the current framework of understanding proffered to him by history. In other words, our decision to fashion ourselves in accordance with the variations available for us in society (be it authentic or inauthentic) plays itself out in accordance with the destining of Being. The leveling down of possibilities which occurs with the reign of das Man as instantiated in the falling-prey of Dasein to inauthentic everydayness is not merely an unfortunate occurence. It is rather the formal structure of existence which gives access to the ontical configurations of the self as proffered by history to Dasein. The self-concealment of Dasein's essential nature, it seems, is the condition for the possibility for its own manifestation in history. Seen in the light of Heidegger's interpretation of history, the tranquility of everydayness, as discussed in Being and Time, is not merely an ontic restructuring of the self-in-context. It is rather an event, in the authentic sense of the word, i.e., a historically destined occurrence.

Given this, it is important to bear in mind that schicken, from the word, Geschick, denotes preparation and ordering. It has something to do with putting something in its proper place, that is, dealing with it according to its own proper nature. In this light, it may be said that any ontic configuration of Dasein's existence (be it authentic or inauthentic) happens according to his own proper essence, as far as the history of Being is concerned. But if such is the case, wherein lies the problematic? Given such an understanding, it seems that everything is always already afforded its proper place by the destining of Being. Why then is there a call towards authentic selfhood? Why does Heidegger put so much emphasis on the irreparable damage that devastation and the growing wasteland can bring, which can spoil all possibility of (re)building and regaining our authentic selves, if this indeed happens in accordance with the provision of destining?

\section{THE FOURFOLD AND THE REMEMBRANCE OF THE NEAR}

Devastation, within the context of the exposition so far, means man's estrangement from his appropriate place in history. However, as mentioned, this devastation is not merely a result of man's doing, nor is it something simply fated to happen by chance. The devastation that devastates everything that has been built and prevents any future building to ensue, hap- 
pens in accordance with the essential unfolding of all that is. It denotes the self-nihililation of beings that occurs in the age of oblivion as appropriated and proffered by the destining of Being.

According to Heidegger, this event proves to be that which is most thought-provoking. The devastation of the earth, of the sky, of the divinities and of mortals is most worth of thought. ${ }^{6}$ As devastation sweeps across the landscape of modern technological society, man is called upon to contemplate this occurrence in view of preparation-a certain collected vigilance that holds itself together in view of that which is yet to come. Heidegger elaborates:

The self-denying of the truth of Being, which entraps itself with oblivion, harbors the favor as yet ungranted, that this self-entrapping will turn about; that, in such turning, oblivion will turn and become the safekeeping belonging to the coming to presence of being, instead of allowing that coming to presence to fall into disguise. In the coming to presence of the danger there comes to presence and dwells a favor, namely, the favor of the turning about of the oblivion of being into the truth of being. In the coming to presence of the danger, where it is as the danger, is the turning about into the safekeeping, is the safekeeping itself, is the saving power of being. ("The Turning" 43-44)

The yet ungranted favor of rebirth and renewal is safeguarded by the coming to presence of withdrawal and concealment. The sudden turning that can occur in a flash of an eye (Augenblick) is held by Heidegger to be the dimension that asks for our preparation and that which may aid us in finding a genuine self. In another work, Heidegger calls for us to comport ourselves in the manner of a releasement, a composed steadfastness that is tantamount to a moving-into-nearness, towards "that-which-regions: an abiding expanse, which, gathering all, opens itself, so that in it openness is halted and held, letting everything merge into its own resting"

${ }^{6}$ In his later writings, Heidegger reappropriates his original intention of uncovering the mystery of Being by way of an ontological analytic of temporal Dasein. After the turn (Die Kehre), he pays more attention to time itself and interpreted it as the horizon of all horizons. The simple and dynamic unity of earth, sky, divinities and mortals, also known as the fourfold precisely signifies the event-character of Being within the horizon of time. The "worlding of the world," as he calls it, happens in accordance with the temporal appropriation of the fourfold, which he calls the event of appropriation (das Ereignis). In other words, history (time itself) happens due to the mirror-play between the four. Things are initiated and gathered in their nature (as they simultaneously gather the fourfold in themselves) within the said horizon, or the so-called clearing (Lichtung). 
("Conversation on a Country Path" 66). Such a comportment of readiness requires man to actively engage an event that is yet to come, and therefore calls him to think and act within the bounds of concealment and oblivion. It requires a leap (Sprung) from a kind of thinking which compulsively calculates and is perpetually preoccupied with merely what is at hand, towards a manner of thinking that allocates space for historical events, essentially understood. Heidegger explains:

For the leap itself, this means that it leaps neither away from the leapingoff realm, nor forward into a different, sequestered domain. The leap only remains the leap as a leap that recollectively thinks upon [the Geschick]. However, recollectively thinking-upon [An-denken] the Geschick that has-been means to bear in mind [bedenken] that which, in what hasbeen, is still unthought as that which is to be thought. Only a thinking that is a fore-thinking [vor-denkendes] responds to this. To recollectively think-upon what has-been is to fore-think into the unthought that is to be thought. To think is to recollectively fore-think. It neither dwells on what has-been as a past represented by historiography, nor is it a representational thinking that stares with prophetical pretenses into a supposedly known future. Thinking as a recollective fore-thinking is the leaping of the leap. This leap [Sprung] is a movement [Satz] to which thinking submits. (The Principle of Reason 94)

That-which-regions, presumably the locale of presencing itself, shelters and is the happening of history. As Dasein, we are appropriated within the expanse of this horizon because we belong to it. "That-which-regions" is another name for the fourfold, the temporal mirror-play of the earth and sky, divinities and mortals and the "in-dwelling in releasement tothat-which-regions would then be the real nature of the spontaneity of thinking" ("Coversation on a Country Path" 82). Releasement, therefore, involves recollective fore-thinking which examines the origin of the devastation in view of re-building, but a building that is now attuned to the essential state of affairs. If devastation is destined, building must begin anew in light of this realization. It must seek to do justice to the historical unfolding of Being and thoughtfully retrieve the mystery of concealment by recognizing our essential place within the nexus of the fourfold, that is, the world. J.L. Mehta expounds on this matter:

Man is man insofar as he has his home on the earth, under the heavens, in front of the gods, with his fellowmen. Mortals are in the fourfold in the sense that they truly dwell in the world, that they care for, cherish and 
tend the fourfold by saving the earth and leaving it free in its essence as earth, by receiving the heaven as heaven, by awaiting the arrival of the gods, by shepherding themselves, in their own essence, towards death. But for mortals, the sole way of dwelling is through their sojourn with things. Only in such sojourn with things is it possible for men to enter into relation with Being and the world. We are, as Heidegger puts it, in the strict sense of the term, the be-thinged (conditioned by our relationship with things). And the fourfold is preserved in the things only when they are allowed to unfold their own nature as things through cultivatingbuilding care of man. Man dwells in so far as he builds and the essence of building is to permit true dwelling-with things. (221-22)

Heidegger places great emphasis on man's relationship with things. For him, things hold within themselves the key to truly understand where we stand in the world. He retrieves the essential meaning of the word "thing" as primordially signifying a sort of gathering or assembly ("Building Dwelling Thinking" 151). A thing in its essential sense, for Heidegger is not a mere object that is present-at-hand, manipulated, controlled and challenged by calculative thinking. "Whatever becomes a thing occurs out of the ringing of the world's mirror-play" ("The Thing" 179). The world is nothing else than the fourfold. The fourfold is the tempo-historical play where Being happens. The mirroring between earth and sky, divinities and mortals "appropriates their own presencing into simple belonging to one another" ("The Thing" 177). Things have the ability to gather the world (the fourfold) and be gathered within the play of the world if they have been produced in accordance with the directives of genuine building, which in turn proceeds from man's essential place in the fourfold as a thinking mortal dweller. Building, tracing its etymological roots from the word "bauen" is related to the Old English word "buan," which means to dwell ("Building Dwelling Thinking" 144). Heidegger elaborates:

The way in which you are and I am, the manner in which we humans are on this earth, is Buan, dwelling. To be a human being means to be on the earth as a mortal. It means to dwell. The old word bauen, which says that man is insofar as he dwells, this word bauen however also means at the same time to cherish and protect, to preserve and care for, specifically to till the soil, to cultivate the vine. Such building only takes care-it tends the growth that ripens into its fruit of its own accord. ("Building Dwelling Thinking" 145) 
Man's primordial existence is inextricably tied with the worlding of the world. As a dweller, his entire being is projected towards the dynamic interplay of the elements that are appropriated with each other in the fourfold. Dwelling consists in providing space for the occurrence of the mirror-play of the four. Such a space is allocated and built in view of a gathering (logos) that brings to view (phasis) the concealed nature of presencing hidden and sheltered in things. ${ }^{7}$ The gathering forth of the four happens insofar as things are built and kept within the purview of genuine thinking, which for Heidegger, is always poetic in nature. Dwelling is not simply accomplished by staying in a particular place. Dwelling happens by precisely allowing any place to have a place for things and for things to create places that allow for gatherings to take place. Mortals are called upon to build things and preserve places that can shelter beings in accordance with the primordial destining issuing from the concealed withdrawal of Being. In other words, dwelling is releasement (Gelassenheit), a thoughtful abidance and staying with things as they unfold within the horizon of that-which-regions. As Heidegger states, "Dwelling preserves the fourfold by bringing the presencing of the fourfold into things. But things themselves secure the fourfold only when they themselves as things are let be in their presencing" ("Building Dwelling Thinking" 149). Dwelling therefore, denotes gratitude towards the gift of absence which allows space for the shining-forth of things, as they silently and unobtrusively remind us of where we stand in history. To let something be is to pay tribute to the withdrawal of presencing in favor of things, as things, in turn, provide space for us to think of the providence of this withdrawal. Building which derives from authentic dwelling is therefore a letting. To build is to prepare, cultivate and preserve space for the fourfold, which simultaneously shelters and protects our essential place in the world as dwellers. To be is to dwell. To dwell is to build. Heidegger elaborates:

Building puts up locations that make space and a site for the fourfold. From the simple oneness in which earth and sky, divinities and mortals belong together, building receives the directive for its erecting of locations.

${ }^{7}$ In "Building Dwelling Thinking," Heidegger uses the example of a bridge, which according to him, gathers the fourfold in its very presencing. It preserves space for the earth to be presented as a landscape around the stream, it unobtrusively lets the divinities present themselves to mortals who cross the bridge everyday (as in the figure of a saint of the bridge), perhaps reminded of the passage of time as the sun rises and casts its light upon the figures passing on the bridge. For an extended explanation of this point, see "Building Dwelling Thinking" 147-52. 
Building takes over from the fourfold the standard for all the traversing and measuring of spaces that in each case are provided for by the locations that have been founded. The edifices guard the fourfold. They are things that in their own way preserve the fourfold. ("Building Dwelling Thinking" 156)

Thus, in the face of devastation man as a mortal dweller is called upon to recall his original essence, that is, his origin-al space within the fourfold. He is given the task of remembering that which has yet to come to pass. In attending to this duty, he is called upon to build and preserve locations that can accommodate the unobtrusive worlding of the world, thereby furnishing a place for the possibility of overcoming the devastation by building things that will precisely remind him of the reality of devastation, that is, of the positive character of withdrawal, concealment and oblivion. This is how Heidegger explains the positive character of withdrawal. The self, after falling prey to the idle chatter of the busyness of contemporary existence must summon the courage to release himself from the tranquilizing comfort of everydayness by listening to silence and fixing his gaze at the yet-to-be visible-Being itself. A self in utter disarray can only gather itself when it allows itself to be gathered by the gathering of the fourfold where genuine re-orientation can begin. As a dweller, the self is incited by none other than history itself to remember his forgetfulness and build himself anew.

\section{THE POETIC}

The revival and renewal of the self depends upon man's compliance with the call of Being. For Heidegger, it is by way of hearkening to the silent call of the near through poetry that mortal man first establishes a firm footing upon the earth, under the sky, as he awaits the divinities. Poetry for Heidegger is no mere play of words or a verbose form of flattery. For him, "poetry first causes dwelling to be dwelling" ("Poetically Man Dwells" 213). The poetic distinguishes man from other beings because it is only man that can attempt to navigate and approximate his place as he stands on the earth, under the sky, among others, before the divine. The poetic engages the unthought as unthought, reveals the concealed as it is and marks the original beginning of history.

All building and making, as that of a craftsman, originally belonged to the realm of the poetic. Technē, Heidegger explains, "belongs to bringingforth, to poiessis" ("The Question Concerning Technology" 13). Poetry and techne both belong to the realm of truth, i.e., alètheia. The light of 
unconcealment prevails in the happening of building and saying that take their directive from the concealed nature of presencing. The revealing that takes place in poiessis is history itself. Authentic poetizing and thinking both build for the sake of dwelling. As one poetizes thought and informs poetry with authentic thinking, one participates in making history-one historicizes one's being.

The historical character of authentic building, thinking and poetizing always shows the span between the human and the divine. That which is most near and most familiar has always already established a relation with that which is farthest and most strange. But the establishment of this relation, albeit ontological in nature, can only be brought to bear upon history when it is spoken of. As George Joseph Seidel elaborates:

According to Hölderlin's words, man spans the dimension by measuring himself against the heavenly. Man does not undertake this spanning just now and then; rather, man is man at all only in such spanning. This is why he can indeed block this spanning, trim it, and disfigure it, but he can never evade it. Man, as man has always measured himself with and against something heavenly... The godhead is the "measure" with which man measures out his dwelling, his stay on the earth beneath the sky. (147)

The godhead, that which is farthest and remains most hidden from man is the so-called measure with which man evaluates the quality of his stay on earth. History has proffered for these two to remain alien to each other and by being so, appropriated to each other appropriately, with respect to their essential natures. The relevance of poetry lies in its ability to speak about the unknown and the hidden with reverence and honesty. As finite, the human person seems to be held down and distracted by the immediate concerns of what he perceives to be worthy of care, but in fact, his ontological predisposition to care transcends the tranquility of his everyday concerns and traverses the infinite abyss that binds and separates men from the divine. This transcendence happens in the realm of the poetic. The poet, through thoughtful words, allows the godhead to remain hidden (safeguarded) from the devastation of mundane everydayness as its image is violently projected in a manifold of ways by men who seek it. The poet keeps the gods, and every thing for that matter, safe from the calculating gaze of reason and discloses the infinite expanse that separates the mortals from the unknowable. In other words, the poet's words measure the distance between the earth and the divinities, between the familiar and the strange. Poetry takes care of the fourfold. Heidegger explains: 
The measure consists in the way in which the god who remains unknown, is revealed as such by the sky. God's appearance through the sky consists in a disclosing that lets us see what conceals itself, but lets us see it not by seeking to wrest what is concealed out of its concealedness, but only by guarding the concealed in its self-concealment. Thus the unknown god appears as the unknown by way of the sky's manifestness. This appearance is the measure against which man measures himself. ("Poetically Man Dwells" 221)

Therefore, when one for instance builds in view of the essential, the thing built serves as a response to the measure. The alien is invited to be near the familiar without necessarily leaving its essential place beyond the sky, kept from the view of mortals. Poetry therefore, as a bringing forth is the proper function of dwelling. Dwellers build their houses, their roads, their bridges, their churches and everything else poetically, that is, in accordance with the devastating absence of the most thought-worthy, the most strange. When one ponders devastation in this light, it no longer signifies the desolation of hopeless wandering, but the possibility of a sojourn in every thing. The conquest of devastation will not be accomplished by the hapless compulsion of man to re-design and refurbish things in the hope of making them last longer or making them easier to deal with. It occurs through the inconspicuous ruminations of a poet as he struggles with words to describe the noumenal, as it were. It happens in the sudden epiphany of a traveler who notices an old rosary dangling from an old taxicab's rear view mirror, calling him to kindness-even towards strangers.

Amidst the devastation that rages over the modern technological milieu, Heidegger invites us to build anew. The disappearance of our gods, the destruction of the earth and the wrath of the sky are not omens that signal the coming of the end. They suggest the self-withdrawal of the truth of Being. They signify the coming to presence of the destining of a generous absence-a self-nihilating absence that proffers the coming to pass of history. As we prepare and safeguard a place for the sudden Turning of Being, we begin to build in accordance with our essential nature as dwellers. We now take our directive from the words of the poet. As Heidegger says, "Man is capable of such building only if he already builds in the sense of the poetic taking of measure. Authentic building occurs so far as there are poets; such poets take the measure for architecture, the structure of dwelling" ("Poetically Man Dwells" 225). The contemplation of the devastation is the task of poetic building. It is only through re-acquainting ourselves with distance that we gain nearness; it is through leaving room for absence that things may once again make their presence felt, enjoining us 
to stay with them, to remain with that which is most thought-provoking, to have an authentic discourse with ourselves as mortals. Genuine dwelling, therefore, consists in the devastation of devastation-in mapping out the presence of a lingering absence in view of preparation for that which is yet to come.

In a world where selfhood seems to be inundated by virtual possibilities and social networks, there is a call to dwell, to gather ourselves and to stay put. To stay and dwell with the strangeness of presencing is a way for us to begin letting ourselves become authentic participants in the happening of history. Amidst the hypnotizing frenzy of real-life and hyperrealized online possibilities for self-configuration that relentlessly challenge us to fit in and be normal, Heidegger invites us to look at our dwelling place and see how things are, and how they generously share their presence with us-such is $a$ way to rebuild, such is $a$ way to be. The self is therefore not something that we indiscriminately appropriate for ourselves in accordance with fashion or necessity. The self is essentially poetic. The self is a function of a greater event-the unfolding of Being itself in history, directing us to recall our authentic place in it, showing us where to go, what to build and how to be.

\section{WORKS CITED}

Heidegger, Martin. "Anaximander Fragment.” Early Greek Thinking. Trans. David Farrell Krell and Frank A. Capuzzi. San Francisco: Harper, 1975. 13-58. Print.

-_- "Building Dwelling Thinking." Poetry, Language, Thought. Trans. Albert Hofstadter. New York: Harper, 2001. 141-59. Print.

--- "Conversation on a Country Path about Thinking." Discourse on Thinking. Trans. John M. Anderson and E. Hans Freund. New York: Harper, 1966. 58-90. Print.

---. "Letter on 'Humanism'." Trans. Frank A. Capuzzi. Pathmarks. Ed. William McNeill. Cambridge: Cambridge UP, 1998. 239-76. Print.

---. "On the Question of Being." Trans. William McNeill. Pathmarks. Ed.William McNeill. Cambridge: Cambridge UP, 1998. 291-322. Print.

--_. "Poetically Man Dwells." Poetry, Language, Thought. Trans. Albert Hofstadter. New York: Harper, 2001. 209-227. Print.

---. "Recollection in Metaphysics." The End of Philosophy. Trans. Joan Stambaugh. New York: Harper, 1973. 75-83. Print.

---. "The Question Concerning Technology." The Question Concerning Technology and Other Essays. Trans. William Lovitt. New York: Harper, 1977. 3-35. Print.

---. "The Thing." Poetry, Language, Thought. Trans. Albert Hofstadter. New York: Harper, 2001. 161-84. Print.

---. "The Turning." The Question Concerning Technology and Other Essays. Trans. William 
Lovitt. New York: Harper, 1977. 36-49. Print.

---. The Principle of Reason. Trans. Reginald Lilly. Indiana: Indiana UP, 1996. Print.

--- What Is Called Thinking. Trans. J. Glenn Gray. New York: Harper, 1968. Print.

Mehta, J.L. The Philosophy of Martin Heidegger. New York: Harper, 1971. Print.

Seidel, George Joseph. Martin Heidegger and the Pre-Socratics. Nebraska: U of Nebraska P, 1964. Print.

Marc Oliver D. Pasco is an Instructor for the Department of Philosophy of the Ateneo de Manila University. He teaches courses on the Philosophy of the Human Person, the Philosophy of Religion, and Foundations of Moral Value. He is currently enrolled in the Ph.D. program of the Department of Philosophy. He has published articles for the Loyola Schools Review: Humanities Edition, Ad Veritatem, Prajna Vihara, as well as a chapter in Agenda for Hope: Governance. His research interests include Heidegger, Baudrillard, Media, and Culture. 